\title{
Ringed hair disease
}

INSERM

\section{Source}

INSERM. (1999). Orphanet: an online rare disease and orphan drug data base. Ringed hair disease. ORPHA:169

Pili annulati is an isolated, benign hair shaft abnormality, usually presenting after the age of 2 and affecting the hair of the scalp or very rarely beard, axillary, or pubic hair, that is characterized by a banded or speckled appearance due to alternating light bands (corresponding to air-filled cavities within the cortex of the affected hair shafts) and dark bands. The bands have a lifelong duration, may only be detectable under light microscopy, are more apparent in fair-colored hair or with age-related graying, and have no effect on hair growth or fragility in the vast majority of cases. 